\title{
APRESIASI KARYA SASTRA SEBAGAI MEDIA PENANAMAN MORALITAS DALAM DAKWAH
}

\author{
Ika Selviana \\ Institut Agama Islam Negeri (IAIN) Metro \\ Jalan Ki Hajar Dewantara 15 A Iring Mulyo Kota Metro \\ nadashobah89@gmail.com
}

\begin{abstract}
Literary work is a subtle medium in conveying the values of morality in da'wah. The beauty of words in literature can provide entertainment and imply the values of personality that can teach goodness.

So many moral values that can be presented by literary works as a means of someone to convey the message of da'wah with beautiful sentences. So in addition to the works of literature can provide entertainment, the readers can also reap the wisdom of the message of da'wah presented the author with a beautiful and interesting language. The moral value can also be derived from the character of the story in the novel as well as from the beauty of the poetic sentence presented by a poet.

The theme of love in literature such as the simple novel "Garis Waktu" from Fiersa Besari and the anthology of "Asal Muasal Pelukan" from Chandra Malik is an alternative to reading that is not only entertaining but implies moral values. although the main theme in this literary work is not including religious themes, but this work contains many good moral values and can be applied in the behavior of community life. da'wah method through literary works is expected to be an alternative in the planting of morality without a sense of patronizing.
\end{abstract}

Key words: literary works, da'wah, moral values

\section{A. PENDAHULUAN}

Di era globalisasi saat ini, perkembangan teknologi dan masuknya budayabudaya luar negeri memberikan dampak positif maupun negatif. Perkembangan teknologi dan budaya ini mempengaruhi kondisi moral dan perilaku masyarakat. Dengan adanya kecanggihan teknologi, banyak berita dan konten-konten negatif yang menyebar luas tanpa mengenal faktor usia dan pendidikan. Hal tersebut menyebabkan munculnya fenomena pergeseran nilai moral. Faktor-faktor yang menyebabkan bergesernya moral dan perilaku masyarakat adalah media informasi mulai dari televisi dan media internet. 
Karya sastra merupakan media cetak yang saat ini hanya disukai oleh beberapa kalangan saja. Banyak masyarakat mengenal karya sastra justru pada saat karya tersebut sudah diangkat menjadi film atau layar lebar, padahal dengan membaca karya sastra secara langsung seseorang bisa menikmati suasana di manapun setting cerita digambarkan meski tidak menikmati alamnya secara nyata. Keindahan kata-kata dalam karya sastra dapat memberikan hiburan sekaligus menyiratkan nilai-nilai kepribadian yang dapat mengajarkan kebaikan.

Menurut Wellek dan Warren, karya sastra dapat dilihat sebagai suatu sistem tanda yang utuh, struktur tanda yang memiliki fungsi dan tujuan estetis. Tanda-tanda tersebut dijadikan para penulis memiliki fungsi didaktis yang tidak hanya akan membuat indera seorang pembaca dapat merasakan pengalaman atau kejadian yang ada di dalam karya sastra tetapi juga memberikan pengajaran mengenai nilai-nilai moral. ${ }^{1}$

Sastra selain mempunyai fungsi rekreatif juga mempunyai fungsi moralitas. Fungsi Rekreatif, yaitu sastra dapat memberikan hiburan yang menyenangkan bagi penikmat atau pembacanya, sedangkan Fungsi Moralitas, yaitu sastra mampu memberikan pengetahuan kepada pembaca atau peminatnya sehingga tahu moral yang baik dan buruk karena sastra yang baik selalu mengandung moral yang tinggi. ${ }^{2} \mathrm{Hal}$ ini memberikan suasana baru bagi masyarakat yang merasa tidak tertarik dengan ceramah-ceramah berbentuk dakwah bil lisan.

Karya sastra memberikan hiburan dan dapat mengajarkan perilakuperilaku yang baik dengan bahasa halus melalui contoh-contoh kehidupan dan perilaku tokoh. Hal yang paling tepat adalah jenis karya sastra berbentuk fiksi baik itu puisi maupun novel, karena di dalamnya pembaca dapat melihat keadaan maupun kisah seorang tokoh sekaligus mengambil pelajaran moral yang baik sambil menikmati cerita dan menghibur diri untuk memperoleh kepuasaan batin.

Sebuah karya sastra berbentuk puisi dan novel dapat mendeskripsikan makna dalam keindahan bahasa dan perwatakan tokoh secara psikologis juga aspek-aspek pemikirannya. Secara tidak langsung pembaca dapat terhibur dengan bahasa maupun alur cerita yang disampaikan penulis tetapi juga mendapatkan contoh secara langsung mengenai perilaku atau moral dari para tokoh dalam puisi maupun cerita. Bentuk sastra ini dapat menjadi media yang halus sebagai sarana perbaikan perilaku pembaca terutama masyarakat masa kini yang lebih menyukai melihat hiburan daripada mendengarkan ceramah. Karena pada dasarnya seseorang lebih suka diberikan contoh secara langsung

${ }^{1}$ Rene Wellek dan Austin Warren, Teori Kesusasteraan, (Jakarta: Gramedia, 1993), h. 159.

2 Alfian Rokhmansyah, Studi dan Pengkajian Sastra: Perkenalan Awal terhadap Ilmu Sastra, (Yogyakarta: Graha Ilmu, 2014), h. 8. 
dan tampak nyata dari pada diberikan nasehat ataupun petuah yang monoton dan menggurui.

\section{B. TINJAUAN TEORI}

Dalam Kamus Istilah Sastra dijelaskan sastra adalah karya lisan atau tertulis yang memiliki berbagai ciri keunggulan seperti keorisinalan, keartistikan, keindahan dalam isi dan ungkapannya. sastra adalah karya sastra dan kegiatan seni yang berhubungan dengan ekspresi dan penciptaan. Sastra bukanlah ilmu tetapi seni.Dalam seni banyak unsur kemanusiaan yang masuk, khususnya perasaan; sehinga sulit diterapkan untuk metode keilmuan.Hakikat sastra tidak bersifat universal dan abadi.Sastra tergantung pada tempat dan waktu. ${ }^{3}$

Pengertian sastra menurut Fananie yang berpijak pada pendapat Mukarovsky memberi pengertian sastra berdasarkan aspek estetika bahasa dan esteika makna.Yakni sastra adalah karya fiksi yang merupakan hasil kreasi berdasarkan luapan emosi yang spontan yang mampu mengungkapkan aspek estetik baik yang didasarkan aspek kebahasaan maupun aspek makna.Estetika bahasa biasanya diungkapkan melalui aspek puitik atau poetic function, sedangkan estetika makna dapat terungkap melalui aspek deep structure. ${ }^{4}$

Sastra memberi ajaran-ajaran kebajikan sekaligus hiburan.Sastra dapat memberikan kepada penikmatnya keindahan dan kegunaan. Inilah salah satu fungsi sastra yang oleh Horatius disebut dulce et utile. Senada dengan ungkapan dulce et utile-nya Horatius, dinyatakan oleh Edgar Allan Poe penyair dan cerpenis Amerika sebagaimana dikutip oleh Rene Wellek \& Austin Warren bahwa sastra berfungsi menghibur sekaligus mengajarkan sesuatu. Secara mendasar, Sastra setidak-tidaknya harus mengungkapkan atau mengandung tiga aspek utama, yaitu decore (memberikan sesuatu kepada pembaca), delectare( memberikan kenikmatan melalui unsur estetik), dan movore (mampu menggerakkan kreativitas pembaca). ${ }^{6}$

Menurut Alfilan Rokhmansyah (2014) dalam kehidupan masyarakat sastra mempunyai beberapa fungsi, yaitu:

Pertama, Fungsi Rekreatif, yaitu sastra dapat memberikan hiburan yang menyenangkan bagi penikmat atau pembacanya.

Kedua, Fungsi Didaktif, yaitu sastra mampu megarahkan atau mendidik pembacanya karena nilai-nilai kebenaran dan kebaikan yang terkandung di dalamnya

${ }^{3}$ Panuti Sudjiman, Kamus Istilah Sastra, (Jakarta: Gramedia, 1984), h. 6.

4 Zainuddin Fananie, Telaah Sastra, (Surakarta: IKIP Muhamadiyah Press, 2001) h.

6

5 A. Nuryatin, Mengabadikan Pengalaman dalam Cerpen, (Rembang: Yayasan Adhiguna, 2010), h. 4.

${ }^{6}$ Rene Wellek dan Austin Warren, Teori Kesusasteraan, (Jakarta: Gramedia, 1989), h. 24 . 
Ketiga, Fungsi Estetis, yaitu sastra mampu memberikan keindahan bagi penikmat atau pembacanya karena sifat keindahannya

Keempat, Fungsi Moralitas, yaitu sastra mampu memberikan pengetahuan kepada pembaca atau peminatnya sehingga tahu moral yang baik dan buruk karena sastra yang baik selalu mengandung moral yang tinggi

Kelima, Fungsi Religius, yaitu sastrapun menghasilkan karya-karya yang mengandung ajaran agama yang dapat diteladani para penikmat atau pembaca sastra. ${ }^{7}$

\section{Wujud Nilai Moral yang Berkaitan Dalam Kehidupan Manusia Dengan Diri Sendiri atu individual}

Nilai moral individual adalah nilai moral yang menyangkut hubungan manusia dengan kehidupan diri pribadi atau cara manusia memperlakukan diri pribadi. Nilai moral tersebut mendasari dan menjadi panduan hidup manusia yang merupakan arah dan aturan yang perlu dilakukan dalam kehidupan pribadinya. Nilai kepribadian itu digunakan untuk melangsungkan, mempertahankan dan mengem-bangkan yang merupakan prinsip pemandu dalam mengambil kebijaksanaan hidup pribadinya.

Untuk semua hal itu manusia harus memenuhi kebutuhan-kebutuhan jasmani, dan rohani dengan cara-cara yang benar didasari dan dituntun oleh nilai-nilai kebenaran dan ditujukan kepada tujuan-tujuan yang benar pula, sehingga tidak akan merugikan orang lain. Nilai moral dalam hubungan manusia dengan diri sendiri pada dasarnya merupakan nilai kepribadian manusia. Nilai kepribadian yang mendasari dan menjadi panduan hidup pribadi manusia. Menurut Simongkir nilai kepribadian merupakan arahan dan aturan yang perlu dilakukan sebagai pribadi manusia. Kepribadian merupakan sifat jasmaniah dan rohaniah yang terealisasikan dalam bentuk tabiat dan tingkah laku yang membedakan seseorang dengan orang lain. ${ }^{8}$

Nilai moral individual diperlukan oleh setiap manusia. Nilai moral individual akan mendorong manusia untuk mencapai kebahagiaan dan kesempurnaan hidup sebagai pribadi melalui pemanfaatan seluruh potensi, kemampuan, dan keterampilan yang dimilikinya tanpa merugikan orang lain. Perlunya nilai moral individual itu bagi manusia didasarkan pada kenyataan bahwa dalam melangsungkan hidup, manusia memerlukan hal yang bersifat jasmaniah dan rohaniah dengan cara dan tujuan yang benar. Sastra.

7 Alfian Rokhmansyah, Studi dan Pengkajian Sastra: Perkenalan Awal terhadap Ilmu

8 O. P. Simorangkir, Etika Jabatan, (Jakarta: Aksara Persada Press, 1987), h. 14 


\section{a. Keberanian Hidup}

Mangunsangkoro mengemukakan bahwa keberanian hidup adalah suatu semangat hidup yang membuat orang sanggup menanggung resiko untung rugi, hidup mati tetapi dengan pemikiran yang tenang dan dapat dipertanggungjawabkan', sedangkan menurut Salam (keberanian hidup adalah berani berbuat, berani bertanggung jawab. Berani dalam arti, pengambilan keputusan tersebut sesuai dengan norma dan nilai kebenaran yang berlaku dalam masyarakat. ${ }^{10}$

Berani di sini didorong oleh rasa keikhlasan tidak bersikap ragu dan takut terhadap segala macam rintangan. Kesanggupan menanggung resiko juga berarti kesanggupan mewujudkan keinginan hidup walau harus melewati rintangan. Kesanggupan tersebut direalisasikan dengan kerja keras dan pantang menyerah. Dengan demikian keberanian hidup bukan hanya berani membela kebenaran tetapi juga mengambil keputusan tanpa ragu-ragu sehingga tidak menghambat kelangsung-an tindakan yang sedang dilaksanakan untuk mencapai tujuan. Salam mengatakan hikmah dari keberanian hidup antara lain: (1) keberanian mendorong manusia untuk mencapai kemajuan, sebagaimana telah dibuktikan oleh orang-orang yang berjasa bagi bangsa, agama, dan kemanusiaan, (2) keberanian menimbulkan ketentraman, (3) keberanian menghilangkan kesulitan dan kepahitan, perasaan sulit sebenarnya berakar pada rasa takut (cemas), jika keberanian timbul maka hilanglah rasa kesulitan dan (4) keberanian membuahkan berbagai kreasi yang produktif atau daya cipta yang berguna. 11

Dalam kehidupan bermasyarakat, keberanian hidup berarti aktifitas manusia yang bertujuan untuk mempertahankan hidup dari ancaman bahaya yang datang dari mahkluk lain maupun ancaman dari luar. Selain itu, keberanian hidup merupakan aktivitas manusia yang bertujuan untuk mengolah dan mengembangkan kehidupan agar tujuan yang ingin di capai dapat terwujud.

\section{b. Nilai Kepribadian dalam Sastra}

Nilai kepribadian adalah nilai yang mendasari dan menjadi panduan hidup pribadi setiap manusia. Nilai itu merupakan arah dan aturan yang perlu dilakukan sebagai hidup pribadi manusia. ${ }^{12}$ Nilai kepribadian ini digunakan individu untuk menentukan sikap dalam mengambil keputusan

${ }_{9}$ S. Mangunsangkoro, Ilmu Adab dan Kemasyarakatan, (Jakarta: Harapan Massa, 1956), h. 42.

10 B. Salam, Etika Sosial: Asas Moral dalam Kehidupan Manusia (Jakarta: Rineka Cipta, 1997), h. 34.

11 B. Salam, Etika Individiual: Pola Dasar Filsafat Moral, (Jakarta: Rineka Cipta, 2000), h. 188

12 O. P. Simorangkir, Etika Jabatan, h. 14 
dalam menjalankan kehidupan pribadi manusia itu sendiri. Lebih dari itu, nilai kepribadian juga digunakan untuk menginterpretasikan hidup ini oleh dan untuk pribadi masing-masing manusia. ${ }^{13}$

Nilai kehidupan pribadi (nilai kepribadian) diperlukan oleh setiap individu. Nilai itu digunakan untuk melangsungkan hidup pribadinya, untuk mempertahankan dan mengembangkan hidup yang merupakan prinsip pemandu dalam mengambil kebijakan hidup. ${ }^{14}$ Perlunya nilai kepribadian bagi kehidupan individu itu dikarenakan setiap individu melakukan segala sesuatu dengan kepribadian yang tampak melalui perbuatan maupun perkataan.

\section{c. Tinjauan Hubungan Nilai Moral dalam Karya Sastra}

Adanya nilai moral dalam karya sastra sebagai pesan, menunjukkan bahwa karya sastra bernilai tinggi. Hal itu karena karya sastra diciptakan pengarang tidak semata-mata mengandalkan bakat dan kemampuan berkreasi, tetapi pengarang melahirkan karya sastra memiliki visi, inspirasi, itikad baik dan juga perjuangan sehingga karya sastra yang dihasilkan bernilai tinggi. Karya sastra senantiasa menawarkan pesan moral yang berhubungan dengan sifat-sifat luhur kemanusiaan, memperjuangkan hak dan martabat manusia. ${ }^{15}$ Sifat-sifat luhur kemanusiaan tersebut pada hakikatnya bersifat universal. Artinya, sifat-sifat itu dimiliki dan gaya kini kebenarannya oleh manusia. Moral dalam karya sastra atau hikmah yang diperoleh pembaca lewat sastra selalu dalam pengertian baik. Dengan demikian, jika dalam sebuah karya sastra ditampilkan sikap dan tingkah laku tokoh-tokoh yang yang kurang terpuji, baik sebagai tokoh antagonis maupun protagonis tidak berarti pengarang menyarankan untuk bertindak kurang terpuji seperti itu.

Sebagai salah satu genre sastra, karya fiksi mengandung unsur-unsur meliputi: (1) pengarang atau narrator, (2) isi penciptaan, (3) media penyampai isi berupa bahasa, dan (4) elemen-elemen fiksional atau unsurunsur instrinsik yang membangun karya sastra itu sendiri sehingga menjadi suatu wacana. Dalam karya sastra termuat pesan kehidupan yang ingin disampaikan pengarang untuk pembaca. Pesan-pesan ini biasanya memberi contoh yang baik dan buruk dalam perbuatan. perbuatan ini dapat dikategorikan dalam nilai moral. Pengarang menonjolkan nilai moral yang berguna bagi manusia.

Kenny mengatakan moral merupakan sesuatu yang ingin disampaikan oleh pengarang kepada pembaca dan makna terkandung dalam sebuah

13 Sukatman, Nilai-nilai Kultural Edukatif dalam Peribahasa Indonesia. Tesis.S2 yang tidak dipublikasikan, (Malang: IKIP Program Pasca Sarjana, 1992), h. 34.

14 Ibid.

15 Burhanudin Nurgiyantoro, Teori Pengkajian Fiksi, (Yogyakarta: UGM, 1995), h. 
karya sastra. ${ }^{16}$ Moral merupakan unsur isi bila ditinjau dari segi bentuk isi karya sastra. Moral kadang-kadang diidentikkan pengertiannya dengan tema meskipun tidak selalu mengarah pada maksud yang sama. Tema bersifat lebih kompleks dari pada moral disamping tidak memiliki nilai langsung sebagai saran yang ditujukan kepada para pembaca. Moral dapat dipandang sebagai salah satu wujud tema dalam bentuk yang sederhana, namun tidak semua tema merupakan moral. Moral dalam karya sastra biasanya mencerminkan pandangan hidup pengarang yang bersangkutan, pandangan tentang nilai-nilai kebenaran dan hal itulah yang ingin disampaikan oleh pembaca.

Wellek dan Warren mengatakan bahwa sastra mempunyai fungsi sosial atau manfaat yang tidak sepenuhnya bersifat pribadi. Studi sastra merupakan masalah sosial yang berisi masalah tradisi, konvensi, norma, jenis sastra, simbol dan mitos. ${ }^{17}$ Sementara Darma menyatakan bahwa sastra identik dengan moral.18 Dikatakan identik karena sastra juga mempelajari masalah manusia yang selalu mengajak pembaca untuk menjujung tinggi norma-norma moral. Sifat-sifat sastra yang menuntut orang untuk melihat kenyataan, kalau perlu yang tidak sejalan dengan kepentingan moral, dan bukannya melihat apa yang seharusnya terjadi. Sementara itu, sastra masih harus melaksanakan tugasnya untuk membentuk jiwa humanitat (tekad manusia untuk menciptakan nilai-nilai yang baik) jauh dari segala sesuatu yang tidak sejalan dengan kepentingan moral. Manusia mempunyai instink untuk memperbaiki dirinya untuk mencapai sifat-sifat luhur kemanusiaan. Sastra sebagai suatu wacana bukan hanya menyenangkan untuk dibaca, tetapi ada hubungannya dengan keperluan sehari-hari. Karya sastra dapat memberikan pengalaman batin, pengetahuan, wawasan hidup, dan sikap moral. Tugas utama sastra adalah sebagai alat penting untuk menggerakkan pembaca pada kenyataan dan menolongnya mengambil keputusan bila ia menghadapi masalah. Oleh karena itu, dapatlah dikatakan bahwa karya sastra mengandung arti yang memberikan manfaat bagi kehidupan manusia.

\section{DAKWAH DAN UNSUR-UNSURNYA}

Menurut Munir Mulkhan dalam bukunya "IDeologisasi Gerakan Dakwah" bahwa dakwah adalah usaha-usaha menyerukan dan menyampaikan kepada perorangan dan seluruh umat manusia dalam hal konsepsi Islam tetnang pandangan dan tujuan hidup manusia di dunia ini, yang meluputi amar ma'ruf nahi munkar dengan berbagai macam cara dan

16 Ibid.

17 Rene Wellek dan Austin Warren, Teori Kesusasteraan, h. 109.

18 Burhanudin Nurgiyantoro, Teori Pengkajian Fiksi, h. 105. 
media yang diperbolehkan akhlaq dan membimbing pengalamnnya dalam perikehiduupan bermasyarakat dan perikehidupan bernegara. ${ }^{19}$

Muh. Ali Aziz menyatakan bahwa dakwah bertujuan mengubah sikap dan mental tingkah laku manusia yang kurang baik menjadi lebih baik atau meningkatkan kualitas iman dan Islam seseorang secara sadar dan timbul dari kemauannya sendiri tanpa ada paksaan atau merasa terpaksa oleh siapa dan karena apa. ${ }^{20}$

Sedangkan menurut Abdul Rosyad Saleh tujuan utama dakwah adalah terwujudnya kebahagiaan dan kesejahteraan hidup di dunia dan di akhirat yang diridloi Allah Subhanahu wa Ta'ala. ${ }^{21}$

Unsur-unsur dakwah adalah;

a. $D a^{\prime} i$

$\mathrm{Da}^{\prime} \mathrm{I}$ atau juru dakwah merupakan poros dari suatu proses dakwah. Secara etimologi, da'I berarti penyampai, pengajar dan peneguh ajaran ke dalam diri mad'u. menurut Muhammad al-ghazali juru dakwah adalah para penasehat, para pemimpin, dan para pemberi peringatan yang member nasehat dengan baik, mangarang dan berkhutbah.22

b. Maddatu al Dakwah (Pesan Illahiyah)

Yaitu ajaran Islam dengan berbagai dimensi dan substansinya, yang dapat dikutip, dan ditafsirkan dari sumbernya (al-Qur'an dan Hadits) atau dapat pula dikutip dari rumusan yang telah disusun oleh para ulama atau da'i. di dalam dakwah pesan ilahiyah dapat disebut juga sebagai materi dakwah, yaitu pesan-pesan yang harus disampaikan oleh subyek kepada obyek dakwah.23

c. Tariqatu al-Dakwah (Metode)

Adalah cara-cara yang digunakan oleh seorang mubaligh (komunikator) untuk mencapat tujuan tertentu atas dasar hikmah dan kasih sayang. ${ }^{24}$

d. Wasilah (Media)

Yaitu sarana yang digunakan dalam berdakwah

e. Mad'u (yang didakwahi)

Yaitu sasaran dakwah

f. Atsar (Efek)

19 AM. Mulkhan, Ideologisasi Gerakan Dakwah, (Yogyakarta: Sipress, 1996), h. 52.

${ }_{20}$ Moh. Ali Aziz, Ilmu Dakwah, (Jakarta: Kencana, 2004), h. 60. h. 21.

${ }^{21}$ Abdul Rosyad Saleh, Manajemen Da'wah Islam, (Jakarta: Bulan Bintang, 1986), 2008), h. 96.

22 M. Ridho Syabibi, Metodologi Ilmu Dakwah, (Yogyakarta: Pustaka Pelajar,

${ }_{23}$ M. Hafi Anshari, Pemahaman dan Pengamalan Dakwah, (Surabaya: Al-Ikhlas, 1993), h. 145

24 Toto Tasmara, Komunikasi Dakwah, (Jakarta: Gaya Media Pratama, 1997), h. 43. 
Adalah suatu efek dari mad'u setelah menerima seruan dakwah.

\section{PEMBAHASAN}

\section{Karya sastra sebagai media Penanaman Moralitas dalam Dakwah}

Karya sastra dan nilai moral sangat erat kaitannya. Karena karya sastra lahir dan berkembang bukan hanya sebagai benda mati atau catatan dari sebuah potret kehidupan tanpa adanya pelajaran dan hikmah yang bisa diambil oleh pembaca.

Dakwah sendiri dalam kaitannya dengan al-Qur'an surat an-Nahl ayat 125 jelas mengajak kepada manusia kepada jalan Tuhan yang berbentuk melakukan kebaikan. Dakwah berkembang dengan berbagai metode dan media. Metode dakwah bil lisan adalah metode dakwah yang banyak dikenal oleh masyarakat. Bentuk metode dakwah bil lisan yaitu ceramah saat ini sudah sangat berkembang luas dengan berbagai materi ceramah dan ragam retorika dari seorang da'i. namun, hal tersebut masih tidak membuat seseorang merasa tertarik mendengarkan ceramah secara langsung ataupun melalui media audio visual. Seseorang lebih suka melihat perbuatan-perbuatan baik secara langsung tanpa ingin digurui dan dinasehati.

Hadirnya karya sastra dapat menjadi alternative bacaan yang bisa dinikmati seseorang yang ingin mencari hiburan namun tetap bisa mendapatkan pelajaran tentang nilai moral. Banyak para penulis yang menghasilkan karya sastra bukan hanya untuk menamppakkan keindahan bahasa dan bunyi tetapi juga menyiratkan kepribadian-kepribadian dan nilai-nilai moral yang baik.

Sebuah novel sederhana berjudul Garis Waktu yang ditulis oleh Fiersa Besari menceritakan sebuah perjalan menghapus luka dengan begitu santai. Karya sastranya ini menggunakan kalimat-kalimat sederhana, mudah dicerna, namun penuh dengan makna.

Seperti kutipan di awal ceritanya:

"Aku lupa bahwa bintang pun bernyawa, hutan pun bernapas, dan kita diciptakan untuk melakukan hal-hal yang lebih besar dari sekadar rutinitas harian. Aku lupa bahwa kita semua terkoneksi; bahwa cinta sepatutnya menjadi bahan bakar agar kita tetap melangkah."

Kutipan di atas menyampaikan bahwa seseorang seharusnya sadar sebagai seorang manusia yang diciptakan dengan kesempurnaan, dan menjadi makhluk yang paling sempurna di muka bumi seharusnya seseorang dapat melakukan sesuatu yang lebih besar daripada sekedar rutinitas harian. Dan dalam kutipan itu juga menyiratkan makna bahwa adanya cinta dalam diri seorang manusia seharunya mampu menjadi bahan bakar motivasinya untuk melakukan hal yang lebih baik untuk mengejar sesuatu. 
Novel ini menceritakan tentang kisah cinta tokoh, tetapi juga banyak memberikan motivasi sebagai media penanaman moralitas bagi pembacanya:

"Jika ingin menetap, jangan menetap sebagai 'tanda tanya', tapi sebagai 'titik' pengembaraan".

Kutipan kalimat ini memaknakan bahwa seseorang seharusnya tidak menciptakan suasana ketidakjelasan dalam pengharapan seseorang. Tetapi seharusnya menjadikannya jelas sebagai awal dari sesuatu yang baru.

Cerita ini juga mengajarkan untuk menghormati pilihan seseorang, dan menghadapi dengan ikhlas kegagalan maupun keberhasilan yang akan dihadapi, serta tidak menyesal akan sebuah keputusan yang sudah dipilih, sebab ujung dari segala kejadian dalam kehidupan ini adalah kematian.

"Entah jalur apa pun yang kita ambil, ujung dari sebuah kehidupan adalah kembali ke tanah".

Kutipan terakhir yang dapat dijadikan motivasi dari cerita ini adalah seseorang harus menghargai dirinya sendiri, karena apapun yang dihadapi dalam kehidupan ini, seperih dan sesulit apapun kondisinya, kehidupan tetap lebih berharga dari semua kesedihan itu. Sebagaimana terlihat dalam kutipan ini:

"Dirimu lebih besar dari sebuah rasa kehilangan, hidupmu lebih agung dari sebuah rasa sakit hati."

Tak berbeda dengan nilai-nilai moral yang bisa dikutip dari cerita di atas, antologi puisi "Asal Muasal Pelukan" Karya Chandra Malik juga memilki banyak makna yang menyiratkan penanaman kepribadian yang baik meskipun masih bertemakan cinta seperti karya sastra sebelumnya. Seperti bait puisi "Kita dan Kata" berikut ini yang meyakinkan seseorang akan kekuatan doa yang dilantunkan untuk orang lain:

"Cinta bukan tanpa kekuatan, Rindu bukan tanpa kelemahan, Namun kita percaya pada keajaiban, Oleh karena itu kita saling mendoakan."

Dalam puisi "Semoga tidak lupa diri" penulis menanamkan nilai moralitas tentang meminta maaf dan memafkan. Seseorang tidak akan luput dari kesalahan, oleh karena itu meminta maaf lebih baik, dan begitupu sebaliknya seseorang mungkin bisa terlukai oleh keliru seseorang oleh karenanya, memberikan maaf adalah lebih mulia.

"Betulku mungkin salah, kelirumu mungkin benar. Tak guna marahmarah, sia-sia saja bertengkar. Minta maaf lebih baik, memaafkan lebih mulia."

Dalam antologi puisi karya Chandra Malik ini selain juga menyebutkan keagungan Nabi, kemuliaan Maulid Nabi dan juga menanamkan perilaku bersyukur. Hakikat bersyukur adalah untuk menerima segala hal dan kondisi dengan ikhlas, sebab di antara segala kesusahan tersimpan adanya kemudahan, begitu pula di balik kesedihan tersingkap adanya 
kebahagiaaan seperti makna tersirat dari puisi "Paling Nyata" dalam antologi ini.

\section{PENUTUP}

Begitu banyak nilai-nilai moral yang dihadirkan oleh karya sastra dapat menjadi sarana seseorang untuk menyampaikan pesan dakwah dengan kalimat-kalimat yang indah. Sehingga selain karya sastra dapat memberikan hiburan, para pembaca juga dapat memetik hikmah dari pesan dakwah yang disajikan penulis dengan bahasa yang indah dan menggungah. Nilai-nilai moral juga bisa diambil dari perwatakan seorang tokoh cerita dalam novel maupun juga dari keindahan kalimat sebuah puisi yang disajikan seorang penyair.

Karya sastra menjadi media alternatif bagi para masyarakat untuk dijadikan sebuah alat untuk memberikan penanaman moralitas baik bagi diri sendiri maupun orang lain. Telah banyak karya-karya sastra yang memiliki banyak nilai moral tersebar di berbagai tempat, bukan hanya karya-karya bergenre islami saja seperti karya Habiburrahman Elsyirazi, Asma Nadia, ataupun Helvy Tiana Rosa, tetapi juga karya-karya sastra bertema cinta seperti kutipan-kutipan di atas.

Dengan bahasa-bahasa yang indah melalui diksi dan bunyi menjadikan karya sastra menjadi media yang halus bagi penyampaian pesan-pesan dakwah secara langsung tanpa adanya kesan menggurui yang kurang disukai seperti bentuk dakwah bil lisan. Ini memberikan motivasi untuk para da'i untuk menghasilkan karya sastra dan menyentuh semua aspek mad'u dengan berbagai usia dan latar belakang, juga mengajak masyarakat umum maupun pengajar membumikan membaca sastra-sastra fiksi dan menjadikannya media untuk menyentuh aspek kepribadian generasi muda yang kurang menyukai dakwah berbentuk ceramah. 


\section{DAFTAR PUSTAKA}

Ancok, D. 2002. Teknik Penyusunan Skala Pengukur. Yogyakarta: Pusat Studi Kependidikan dan Kebijakan, Universitas Gadjah Mada.

Bakker, J. W. M. 1984. Filsafat Kebudayaan. Yogyakarta: Kanisius.

Bertens, K. 2005. Etika. Jakarta: PT Gramedia Pustaka Utama

Danandjaja, James. 2002. Folklor Indonesia. Jakarta: Depdikbud.

Fananie, Zainuddin Telaah Sastra,2001, Surakarta: IKIP Muhamadiyah Press.

Mangunwijaya, Y. B. 1988. Sastra dan Religiositas. Yogyakarta: Kanisius.

Nurgiyantoro, Burhanudin. 1995. Teori Pengkajian Fiksi. Yogyakarta: UGM

Roekhan, 1990, "Kajian Tekstual dalam Psikologi Sastra: Persoalan Teori dan Terapan," dalam Aminuddin (Ed.) Sekitar Masalah Sastra, Malang: YA3.

Salam, B. 1997. Etika Sosial: Asas Moral dalam Kehidupan Manusia. Jakarta: Rineka Cipta.

Simorangkir, O. P. 1987. Etika Jabatan. Jakarta: Aksara Persada Press.

Sukatman. 1992. Nilai-nilai Kultural Edukatif dalam Peribahasa Indonesia. Tesis.S2 yang tidak dipublikasikan. Malang: IKIP Program Pasca Sarjana.

Suparlan, Y. B. 1983. Kamus Istilah Kesejahteraan Sosial. Yogyakarta: Pusat Pembinaan dan Pengembangan Bahasa.

Suseno, Frans Magnis. 1987. Etika Dasar Masalah-masalah Pokok Filsafat Moral. Yogyakarta: Kanisius

Syuhadak. 2010. Nilai-Nilai Kultural Edukatif Dalam "Basanan" Using Banyuwangi Dan Pemanfaatannya Sebagai Alternatif Materi Pembelajaran Apresiasi Sastra Di Sekolah .Skripsi tidak dipublikasikan. FKIP PBSI. Universitas Jember.

Teeuw, A. 1984.Sastra dan Ilmu Sastra. Jakarta: Pustaka Jaya.

Wellek, Rene dan Austin Warren. 1989. Teori Kesusasteraan. Jakarta: Gramedia. 